\title{
The Subject Division Organization In a Liberal Arts College Library:
}

A Commentary

By ANTOINETTE CIOLLI

For ReAsons other than the obvious $\mathbf{F}$ ones, the opening of the extension to the Brooklyn College Library on September 21, 1959, was an important occasion. It provided the library the opportunity to reorganize its public services and enter into a new level of development. The old arrangement of materials by form (with conventional departments: circulation, periodicals, documents, reserve, and reference) was supplanted by subject divisions.

How did this reorganization, which set up humanities, social science, education, and science divisions, affect the role of the librarians? It in no way changed their role-their role remains the same: to further the educational and cultural aims of the college. However, the experience of a year and a half has made it obvious that the reorganization has enabled them the better to play their role in instruction. The reason is implicit in the nature of the subject division arrangement. In each of the four divisions, all books (except reserve books), all periodicals, all government documents (except social science), and all education pamphlets are brought together on open shelves. An author-title catalog is made available in each division except humanities (which is close to the subject catalog). A shelf list is provided in each area. A small core of reference books and all pamphlets except those on education are in each division kept behind the desk. Because a central circulation division is responsible for shelving and charging, librarians in each of the divisions are free to be resource specialists in their areas,
Miss Ciolli is Chief Science Librarian, Brooklyn College Library.

the better to help students and faculty.

As resource specialists, the subject division librarians perform their unique campus function in three ways. First, they select the best books for their subject areas. It is important that the student who is inspired in the classroom should be able to find in the library the material with which to realize his inspiration. It is the prime function of the instructor to influence the reading of the student; it is the function of the librarian to do it less directly by booklists, exhibits, and, most important, by the titles he makes available in his division.

"Nothing on the hydra is on the shelves!" "You need more material on the spiny dogfish." "You have very little on marine biology." "Why don't you have more books on obstetrics?" "Everything is out on parasitical diseases in Africa!"

Plaintive cries such as these, from students who assumed that a perfect book collection would automatically rise from the newly installed shelves, could not help but evoke an immediate response in book orders. Whereas recommendations from the faculty increased by 20.7 per cent, those from librarians increased by 92.8 per cent. ${ }^{1}$ The chief science librarian, alone, requested 572 titles for the science division as against 428 titles rec-

\footnotetext{
1 Brooklyn College Library, Annual Report of the Librarian, 1959-60. (Brooklyn, 1960), p. 3.
}

COLLEGE ANDRESEARCH LIBRARIES 
ommended by eighty-eight faculty members making recommendations. The distribution of book orders by subject inevitably paralleled that of student requests for reference assistance. It was precisely while working with students in the areas of their greatest bibliographical interest that a first-hand knowledge was acquired of the gaps in the collection and steps taken to remedy the situation. Thus, one of the great advantages of the new library organization by subject area - that the librarians in charge can be more effectively responsive to student and faculty needs,-was experienced.

When the open shelves and his own devices have failed him, the student expects the subject division librarians to perform their second unique function: providing reference assistance. It is at this point that the division librarians in a liberal arts college library acutely realize that they are expected to be, at one and the same time, general reference librarians and subject literature specialists. The freshman writing his first term paper for English, the upper classman preparing a speech for her examination in pedagogy, the graduate student in biology-all of these seek material on such topics as the effects of radiation on food, the relation between smoking and lung cancer, or the connection between viruses and diseases, and all expect the subject division librarians to use their best professional judgment in recommending appropriate sources.

The chief science librarian, in delineating the pattern of student use from a year's sampling of the questions asked and recorded at the science desk, found that the number of requests for assistance which involved the use of general science or non-science resources was the third largest single item in the distribution by "type of references used in answer." ${ }^{2}$ This attests the liberal arts orientation of the student users of even such a library

\footnotetext{
2 Brooklyn College Library, Science Division First Annual Report, 1959/60. (Brooklyn, 1960). p. 2.
}

division as science. A substantial body of requests required that the librarians refer the student to abstracts, bibliographies, and indexes outside the science division. Prominent in the latter category were the Education Index, the Child Development Abstracts, the Readers' Guide, the International Index, the Biography Index, and the Sociological Abstracts. At Brooklyn College, the speech area provides a particularly fruitful source of examples of term papers topics which take the student to several divisions of the Library. "Psychogenic deafness," "malingering," "the speech of the brain-injured child"-such topics as these involve primarily the use of the Psychological Abstracts, the Index Medicus, and the Current List of Medical Literature, all of which are part of science, and, in addition, the use of the Education Index and the table of contents of the Quarterly Journal of Speech and Speech Monographs ${ }^{3}$ in humanities!

Although there is no instruction quite so successful as the individual guidance which the subject division librarians give when students request assistance, organized class instruction is essential where large numbers of students are involved. The subject division librarians are, ideally, ultimately responsible for providing systematic instruction in the catalogs, indexes, and bibliographies within their areas. At Brooklyn College, because of limited staff, it was possible to undertake only occasional class instruction in the subject bibliography of education, social science, and physical education. There were great differences in the quantitative and qualitative use of library by students and in their knowledge of basic reference books. In chemistry, the literature is so well organized that the individual guid-

3 It is characteristic of the research literature of the field of speech that it divides into two categories: bibliographic listings on general speech come from the areas of social science and humanities; those on speech science and correction draw upon medicine and physiology. Robert N. Broadus, "The Research Literature of the Field of Speech" ACRL Monographs, No. 5-7 (1953), 22-31. 
ance which the librarian gave in answering reference questions obviated much of the need for group instruction. In physics, mathematics, geology, health education, and home economics, little instructional demand presented itself. However, in biology, psychology, and speech, a good deal of individual instruction in the use of bibliographies, abstracts, and indexes was required. In these areas, it would seem more efficient to give group rather than individual instruction.

If, then, the reorganization of the library has associated librarians more closely with subject areas and, thus, more closely with instruction, it is by no means without its limitations. There is, first, the obvious danger inherent in specialization. The subject division librarians can easily, in attempting to cope with the pressures in their own areas, lose touch with resources in areas other than their own. In an undergraduate organization, where students expect each librarian to continue to give general as well as specialized reference service, this may become a serious handicap. (An effective preventive is a regular turn at the general information desk. Service at this point is one of several necessary means to keep one alive to the whole library picture and not merely to one of its segments.)

A second limitation to the subject division organization is the confusion experienced by students who find it necessary to go to several divisions for material for one term paper. On the whole, partly because the new building is much larger than the old, becoming oriented seems more complicated in the reorganization than in the traditional arrangement.

Finally, the subject division organization requires more librarians and is thus more costly. The Brooklyn College Library staff, with the addition of two new professional positions, is still, after a year and a half, performing in an emergency atmosphere in an endeavor to cope with the greater surge of student demand. It is mainly the enthusiasm and elation in finally moving into a new modern building which is carrying it through.

Only the future will tell whether the advantages of the subject division arrangement outweigh the disadvantages. It can at present be said with certainty, however, that the reorganization in the Brooklyn College Library provides one the experience of practicing librarianship with intensity.

\section{The Monteith Library Project}

(Continued from page 265)

achievement next to impossible. We have purposely postponed facing the problem of evaluating the contribution of library competence to learning, but we cannot avoid recognizing that individualized library assignments add another major variable-the variation among subjects in the amount and organization of materials dealing with them-to a situation already complicated by the individual differences among the students. We hope eventually to be able to make some general statements about what Monteith students have learned as a result of the library's part in their courses. We are certain that we will never be able to say that they might not have learned as much in any of a number of other ways. 